is, of course, a more urgent problem, but there is always a danger that when a mere sufficiency of food dispels obvious signs of trouble, the populations then rid of them will be left without goals at which to aim. The FAO's discovery that there may, after all, be enough food to go round should be a spur to everybody to see that it is properly used in the years ahcad.

\section{Goldfinger No Longer}

JAMes Bond appears on the front of the Odeon cinema, Charing Cross Road, in a characteristic pose. His gun is almost casually held across his chest. It is aimed unmistakably at the offices of the Natural Environment Research Council noxt door.

Those who take pleasure in Bond do so by identifying themsclves with him, and at the moment it is the turn of poor NERC to be at the wrong end of the selfidentified gun barrel of many natural environmenters and not a few of those who thumb through tho annual reports to find inconsistencies, mysteries and strife. Certainly there has bcen plenty to say since the NERC annual report appeared a few weeks ago (see Nature, $224,941 ; 1969)$. As was clear at the time, the problems of NERC are aggravated by its special relationship with big institutions. It has become abundantly clear that the links with the Antarctic Survey, the Institute of Geological Sciences, the National Institute of Oceanography, the Nature Conservancy and other superpowers had not been appreciated by many univer. sity workcrs. The fact that only 15 per cent of NERC's expenditure last year went directly into universities has been received with consternation. Does this explain many of the decisions which have emanated from NERC?

What has gone wrong? The first thing to bo said is that growth industries are bound to suffer when a squecze is applied. On the face of things, it looks as if NERC loaded itself with too many commitments when it was being encouraged to expand. Now the main. tenance of even these commitments, let alone the initialion of projects which new gencrations of research workers cannot be prevented from dreaming up, secms to have become a financial embarrassmont. The figures speak for themselves. Last year's research grants awarded to universities were less than one third of the total rcquested. Were those which failed cntirely without merit? Ominously, the statistics scem to show that large grant requests fare badly. Thus in geology and geophysics (which takes the biggest stice), 141 applications for an average of $£ 10,000$ each were converted into a hundred awards at an average of $\mathfrak{1 4 , 0 0 0}$ each. Thinking big seems to be one certain way to damnation. And the gloom is not all in the university camp-the director of a very sizable undcrtaking in one of the institutes has had his budget for this coming year pruned by 60 per cent.

If money were the only snag, it need not be insurmountable. NERC staff could help to coordinate efforts and perhaps persuade a few isolated research teams to move physically closer together. Then, as noted a year ago, there is no compelling reason why a few geology departments should not merge. But the mood in the universities seems to be bitter. Therc is some suspicion that NERC's big boys are on the hunt for promising research projccts which they can cart off to their respcctive establishments. Whether this is true or not, it is a fear which is so often mentioned that it needs to be dispelled. Equally worrying is the penchant for National Plans, Five Year Looks and the like. Ten months ago, geology and geophysics professors were told by NERC that an effective case for funds from the Treasury would be strengthened by a clearer statcment of strategy. Since then, the promised (or threatened) questionnaires have been very slow in appearing, but whatever the result of this exercise it bodes ill for real free-whecling research. Onee NERC has a generally agreed document on priorities, it is going to be difficult to prevent this being the touchstone for all research allotments. And if the institutions can get their pet projects on the list, it will be thumbs down to the academic who thinks for himself. A private nightmare of one earth scientist is that evcryone will be searching for gravel in the English Channel in ten years' time.

Whatever the fears and fantasies of the universities, two points can be made which do not rely on hearsay or guesswork. The first is that it is arguable that a research council should divest itsclf of supporting the routine data collection that comprises much of the work of the institutions. This is not research and only occasionally aids research. It is far better that it should not bog down the activities of research organiza. tions, financially or otherwise. The second point is that any academic group stands or falls by its publications in the open literature. Prolonged silence is a danger symptom. A large chunk of NERC's money goes, however, to establishments where internal publication is the most common means of dissemination. Is it too much to expect one criterion for continued NERC support to be evidence that the work is subject to the same external controls that others accept by publishing in the open literature?

Times are not going to be easy for NERC in the foreseeable future. Sorting out relationships with institutions and universities is perhaps the first problem. If this is not solved, the militancy which is growing in education might even reach the Charing Cross Road. It does not at first sight seem unreasonable to ask that the council and major committees should be much more directly responsible to the grass roots, or that there should be delegates and observers at important meetings of committees. At present, democracy in the higher echelons of British science is almost non-existent. 